\title{
A case of scurvy in a student
}

\author{
I. J. T. Davies* \\ M.B., M.R.C.P. \\ Registrar
}

\author{
J. M. TEMPERLEY \\ M.A., M.B., B.Chir., M.R.C.P. \\ Senior House Officer
}

Whittington Hospital, London, N.19

Clinical scurvy occurs rarely in this country. It is almost entirely confined to old people subsisting on inadequate diets-so called 'bachelors' scurvy' (Smart, 1966).

We report a case of clinical scurvy presenting with moderately severe anaemia and swelling of the legs in an athletic Nigerian student.

\section{Case report}

A 27-year-old Nigerian student actuary was admitted on 8 December 1966. He had come to England from Lagos in 1959. He complained of painful swelling of the right calf and to a lesser extent of the left calf of 3 weeks' duration. He was a marathon runner of international standard and trained by running 30 miles a day. He had been able to carry out his daily training until 5 weeks before admission when he had first noticed excessive shortness of breath during exercise.

For 2 years his gums had been swollen and had sometimes bled. He was unmarried and cooked for himself. He had never eaten fruit or fresh vegetables.

On examination. He was a fit-looking man, although with marked pallor of the mucous membranes. He was not jaundiced. There were multiple splinter haemorrhages under all the finger nails, which were otherwise normal. The skin was normal. The gums were hypertrophied with areas of bleeding (Fig. 1). There were petechiae on the palate. The right calf was swollen and tender with slight pitting oedema at the ankle. Homan's sign was positive. The left calf was also swollen and tender. There were no other abnormal physical signs. Hess' test was negative.

Investigations. Haemoglobin, $44 \%$; red cells, slightly hypochromic and normocytic; white cell

*Present address: University College Hospital, London,

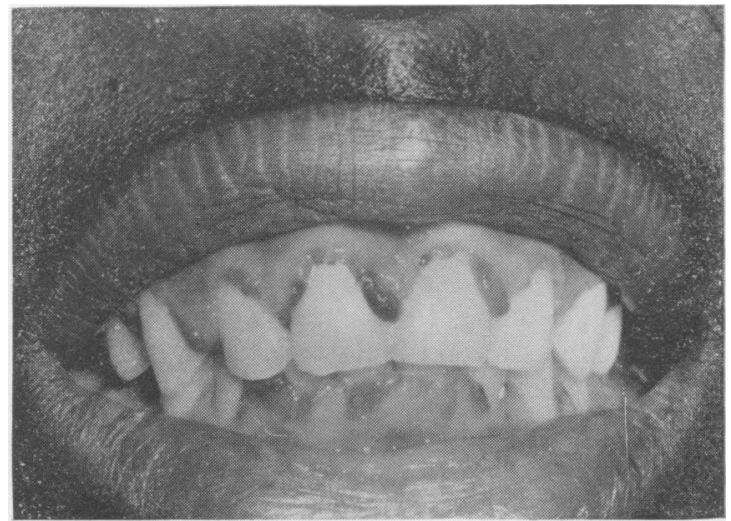

FIG. 1. Bleeding from hypertrophied gums before treatment.

count, $5300 / \mathrm{mm}^{3}$ with a normal differential ; platelet count, normal ; reticulocyte count, $3 \%$; serum bilirubin, $0.8 \mathrm{mg} / 100 \mathrm{ml}$. The urine contained no bilirubin but an excess of urobilinogen.

A vitamin C saturation test (Harris, 1943) was commenced. The signs in the right leg were thought to be due to extravasation of blood. After 3 days in hospital a remarkable improvement in the gums was noted. Besides bed rest and hospital diet the only other treatment that had been given was the daily dose of $700 \mathrm{mg}$ of vitamin $\mathrm{C}$ for the saturation test. The diagnosis of scurvy was later confirmed by this test.

The raised reticulocyte count and excess urobilinogen in the urine suggested a haemolytic process and the following additional investigations were carried out:

Sickling test, negative; red cell fragility, normal; haemoglobin electrophoresis, normal; Coombs' test, negative; WR, negative; serum iron, $40 \mu \mathrm{g} / 100 \mathrm{ml}$; serum folate, $11 \mathrm{~m} \mu \mathrm{g} / \mathrm{ml}$; serum $B_{12}, 250 \mu \mu \mathrm{g} / \mathrm{ml}$. 
Progress. He continued to improve on vitamin $\mathrm{C}$ alone and the reticulocyte count was $10 \%$ after 3 days and the haemoglobin was $56 \%$. After 10 days the reticulocyte count was again $10 \%$ and the haemoglobin was $75 \%$. The legs and gums returned to normal and when he was seen on 6 February 1967 the haemoglobin was $98 \%$.

\section{Discussion}

The anaemia of scurvy is usually normochromic and normocytic (de Gruchy, 1964). However, anaemia is not an invariable accompaniment even of severe scurvy (McMillan \& Inglis, 1944 ; Brown, 1951). Furthermore, in experimental vitamin C deficiency severe anaemia does not occur (Medical Research Council, 1948). It has been suggested that the anaemia of scurvy is due to an associated dietary deficiency of folic acid (Bronte-Stewart, 1953) but the anaemia of scurvy is almost invariably normoblastic even if it is macrocytic (Brown, 1955). Vitamin C may be necessary for the conversion of folic to folinic acid (Nichol \& Welch, 1950; May et al., 1951) because when a megaloblastic anaemia does occur in scurvy it always responds to the administration of vitamin $\mathrm{C}$ alone (Goldberg, 1963). In this case the absence of macrocytosis and the normal serum folate level were thought to indicate a normal folate intake.

The characteristic normochromic, normocytic anaemia of scurvy always responds to vitamin C (Bronte-Stewart, 1953). There is often an increase in serum bilirubin, frequently a reticulocytosis in the peripheral blood and increased urobilinogen excretion in the urine and the survival time of normal red cells transfused into scorbutic patients is reduced (Merskey, 1953 ; Goldberg, 1963). These findings suggest that haemolysis may be a factor in producing anaemia; however they may also be produced by destruction of red cells extravasated into the tissues (Proehl \& May, 1952; BronteStewart, 1953). There is no correlation between the severity of the anaemia and the amount of external blood loss (McMillan \& Inglis, 1944; Vilter, Woodford \& Spies, 1946 ; Bronte-Stewart, 1953 ; Goldberg, 1963). Goldberg (1963) showed in one case using labelled red cells that there was no accumulation of radioactivity in a bruised area, suggesting that continued destruction of circulating red cells does not occur in extravasated blood. Goldberg also suggested that vitamin $\mathrm{C}$ is essential for normal erythropoiesis.

Thus the anaemia of scurvy is probably due to several factors, viz.: (1) extracorpuscular haemolysis, (2) extravasation of blood, (3) relative lack of folinic acid, (4) dyshaemopoiesis, and (5) associated dietary deficiencies. The first four are reversible with vitamin $\mathrm{C}$ alone.
In our patient the anaemia was normochromic and normocytic, and responded to vitamin $\mathrm{C}$, bed rest and routine hospital diet. The case is remarkable in that the disease presented with anaemia, the only other clinical manifestation of scurvy being bleeding from the gums. There was none of the other manifestations of scurvy such as hyperkeratosis, perifollicular haemorrhages or subcutaneous purpura. The case is unusual in that there was no evidence of other dietary deficiency such as folic acid or other vitamins.

\section{Summary}

A case of scurvy presenting with anaemia in an athletic Nigerian student is presented and discussed. The mechanisms responsible for the anaemia of scurvy are briefly reviewed.

\section{Acknowledgment}

We are grateful to $\mathrm{Dr}$ T. St M. Norris for permission to publish this case.

\section{References}

BRONTE-STEWART, B. (1953) The anaemia of adult scurvy.

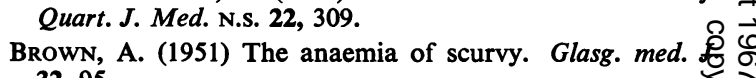
32, 95.

Brown, A. (1955) Megaloblastic anaemia associated wit adult scurvy. Brit. J. Haemat. 1, 345.

GoldBerG, A. (1963) The anaemia of scurvy. Quart. J. Med. N.S. 32, 51.

DE GRUCHY, G.C. (1964) Clinical Haematology in Medical Practice, p. 203. Blackwell Scientific Publications, Oxford.

HARRIS, L.J. (1943) Vitamin C saturation test: standardization measurements of graded levels of intake. Lancet, i, 515.

McMillaN, R.B. \& INGLIS, J.C. (1944) Scurvy: a survey of fifty-three cases. Brit. med. J. ii, 233.

May, C.D., Sundberg, R.D., Schaer, F., Lowe, C.U. \& SALMON, R.J. (1951) Experimental nutritional megaloblastic anemia. Amer. J. Dis. Child. 82, 282.

Medical Research Council (1948) Vitamin C requirement of human adults. Experimental study of Vitamin-C deprivation in man. Lancet, $\mathbf{i}, 853$.

MERSKEY, C. (1953) Survival of transfused red cells in scurvy. Brit. med. J. ii, 1353.

Nichol, C.A. \& Welch, A.D. (1950) Synthesis of $\frac{7}{2}$ citrovorum factor from folic acid by liver slices; augmentation by ascorbic acid. Proc. Soc. exp. Biol. (N.Y.), 74, N 52.

Proent, E.C. \& MAY, C.D. (1952) Experimental nutritional 응 megaloblastic anemia and scurvy in the monkey. III. $N$ Portoporphyrin, coproporphyrin, urobilinogen and iron in the blood and excreta. Blood, 7, 671.

Smart, G.A. (1966) Scurvy. Price's Textbook of the Practice of Medicine (Ed. by R. Bodley Scott), p. 400. Oxford University Press, London.

VILTER, R.W., WoOlford, R.M. \& SPIES, T.D. (1946) Severe scurvy; a clinical and hematologic study. J. Lab. clin. Med. 31, 609. 